\title{
МЕДІЙНА ГЕГЕМОНІЯ КОЛОНІЗАТОРІВ У ПІВДЕННІЙ АФРИЦІ: ВІЗІЯ СТІВА БІКО
}

\author{
Юрій Мельник \\ Львівський національний університет імені Івана Франка, \\ вул. Генерала Чупринки, 49, 79044, Львів, Україна, \\ e-mail: melnykiurii@gmail.com \\ https://orcid.org/0000-0002-2825-9925
}

У статті зроблено спробу оцінити внесок південноафриканського публіциста Стіва Біко у розвиток концепції гегемонії Антоніо Грамші. Режим апартеїду у ПАР, будучи прикладом політичного, економічного, а передусім - культурного панування колонізаторів над колонізованими, унаочнює, яким чином нечисленна меншість, утримуючи контроль над релігією, освітою, громадським життям, домінувала над величезною більшістю населення, яку складали корінні жителі країни. Екстраполяція концепції на сучасні реалії демонструє iii актуальність у національному, міжнаціональному, глобальному вимірах. Серед численних прикладів - російський інформаційний простір, у якому влада контролює мейнстрімові медіа та має достатньо важелів впливу на опозиційні.

Ключові слова: гегемонія, Стів Біко, пропаганда 2.0, медійний імперіалізм, ПАР, апартеїд.

\section{Концепція гегемонії Антоніо Грамші}

Італійський публіцист та філософ-комуніст Антоніо Ірамші у 1930-ті роки вжив поняття «гегемонія» на позначення культурного домінування соціальної групи. Грамші наполягав, що керівна роль одного класу над іншим тримається не на насильстві, а на згоді, добровільному підпорядкуванні. Роман Тиса так розшифровує цю концепцію: «Гегемонія означає не тільки опанувати провідне місце в політикоекономічному житті суспільства, але також мати авторитет в народних мас, культурне та моральне лідерство («культурна гегемонія» або «ідеологічна гегемонія»). Без авторитету панування може означати лише диктатуру. Міць гегемонії знати зі згоди народних мас із політикою панівної кляси. У буржуазному суспільстві культурноідеологічну геґемонію здійснюють інтелєктуали (або «працівники розумової праці») почерез інститути «громадянського суспільства»- - буржуазному суспільстві це школи, церкви, засоби масової інформації, об'єднання громадян тощо» [1].

Мета статті - оцінити внесок південноафриканського публіциста Стіва Біко у розвиток концепції гегемонії Антоніо Грамші.

В контексті вчення Грамші культурна гегемонія буржуазії у західних суспільствах, можливість нав’язувати пролетаріату свої норми, цінності, переконання,

(C) Мельник Ю., 2019 
видаючи їх за універсальні, була тим фактором, який завадив здійснити комуністичну революцію на Заході. (У Росії перемога комунізму була можлива 3 огляду на слабкість буржуазії та, відповідно, відсутність гегемонії буржуазії над народом колишньої Російської імперії). Розглядаючи можливості для нового суспільного консенсусу, у якому за пролетаріатом визнаватиметься його панівна роль, Грамші стверджує, що він можливий за умови культурного домінування пролетаріату, для якого необхідна тривала і клопітка підготовка у сфері культури, науки, освіти [див. детальніше: 2].

Як виявилося, концепція Антоніо Грамші не лише пережила комунізм як ідеологію разом з його архаїчним на сьогодні понятійним апаратом та зовсім закинутими планами про комуністичну революцію на Заході, але й виявилася значно актуальнішою в інформаційну епоху порівняно з епохою, у яку Ірамші їі розробляв. Давно відомо, що культурна гегемонія може бути не лише марксистською, - до цієї грамшіанської концепції виявляв інтерес лідер французьких Нових Правих А. де Бенуа: «Щодо суто методологічних аспектів, то погляди Грамші виявилися пророчими. Не так уже й дивно, що вони змусили лівих та крайніх лівих переглянути їхню стратегію» [3]. Нові праві - не лише французькі - дотримуються грамшіанських методів політичної боротьби і часто декларують прерогативу культурно-ідеологічного розвитку (який дасться взнаки згодом) перед поточними політичними перемогами [див: 4].

Навіть це зауваження не розкриває всієї повноти значення концепції Грамші, масштаби їі теоретичного осмислення та практичного застосування. Сальваторе Скінелло у книзі «Увесь наш інтелект. Концепт гегемонії у Ірамші» справедливо виводить із грамшіанської гегемонії так звану soft power авторства Джозефа С. Ная молодшого, яка, прийшовши на зміну традиційній війні, стала ключовою стратегією утвердження лідерства США у світі (через поширення американського способу життя, масової культури, кінематографу тощо) [5]. Інші гравці, які претендують на глобальне лідерство (Китай, Свросоюз, Росія) теж усе частіше покладаються на м'яку силу, застосовуючи війська дозовано і у випадку крайньої необхідності, - після 1945 р. традиційна, фронтальна війна перестала бути оптимальним способом досягнення своїх інтересів.

Логічним наслідком цих процесів (та водночас фактором який їх суттєво підсилює) є ріст значення медіа та медіатизація усіх суспільних процесів і явищ. Отже, не буде перебільшенням сказати, що домінування в інформаційній сфері стало запорукою культурної гегемонії у грамшіанському сенсі слова. Звідси - поява медійної гегемонії у науковому дискурсі (див. роботи Девіда Алтайда [6], Шона Джонсона Ендрюса [7]).

Таким чином, концепція Ірамші є, по-перше, ідеологічно нейтральною (нідерландський учений Р. ван Краненбург так і не зміг навести жодного переконливого аргументу на користь того, що описану у працях Ірамші тактику можуть застосовувати винятково ліві [див: 8]), а по-друге - все більше пов'язаною з інформаційною сферою, медійним домінуванням.

Розглянута під цим кутом зору «гегемонія» має багато спільного 3 «медійним імперіалізмом», як його розуміють вчені на зразок Олівера Бойд-Барретта. Цей автор бачить медійний імперіалізм у трьох формах відносин: «По-перше, $з$ допомогою чи за посередництвом медіа прийнято в різних сенсах здійснювати, просувати, трансформувати чи ослаблювати процеси імперіалізму, а також протидіяти їм. По-друге, 
3 допомогою і через поточні процеси побудови і підтримки імперії прийнято моделювати самі медіа, значення, які вони виробляють і поширюють, і політико-економічні процеси, які їх підтримують. Також медіа зберігають у собі залишки імперій, які колись існували. По-трете, існує медіа-поведінка, яка сама по собі і безвідносно до більш широких чи більш змістовних структур, можна вважати імперіалістичним». Під імперіалістичною медійною поведінкою Олівер Бойд-Барретт має на увазі «нерівний новинний обмін», який західні міжнародні новинні агентства нав’язують національним агентствам та аналогічні явища у національному масштабі [9, С. 11].

Ще одним спорідненим із гегемонією явищем є т. зв. «пропаганда 2.0», яку в Україні досліджує та описує Георгій Почепцов: «Пропаганда $2.0 €$ пропагандою, захованою всередині літератури і мистецтва, кіно і телесеріалів. Сьогодні місцем її нового проживання стали також новини, які несуть у маси свою власну пропагандистську надбудову» [10]; «Пропаганда 2.0 - це пропаганда професіоналів. У цій системі з'являється важлива естетична складова. Це голос Левітана в одній ситуації, який призвів до того, що він став особистим ворогом Гітлера, але це й чарівність усмішки Тетяни Самойлової чи Одрі Гепберн в іншій. Це телесеріали, де «свої» завжди перемагають «чужих», що, звісно, більш приємно, ніж якби все було навпаки» [11, С. 6].

Поряд із медійним імперіалізмом, пропагандою 2.0 , тісно пов'язаними з медійною гегемонією є такі медійні закономірності, як теорія «agenda-setting» Бернарда Коена (за якою медіа сортують інформацію на «важливу» та «неважливу», формуючи порядок денний) та спіраль мовчання, яку описала Елізабет Ноель-Нойманн (за якою провідні медіа виступають від імені громадської думки, у такий спосіб формуючи іï). Усе це - атрибути, ознаки медійної гегемонії, або ж супутні феномени, механізм роботи яких спрямований на формування оцінок, думок, трендів, норм, стандартів, а в кінцевому підсумку - на максимальний контроль над громадською думкою.

\section{Апартеїд у публіцистиці Стіва Біко}

Стів Біко (1946-1977) - відомий південноафриканський суспільний діяч часів апартеїду, борець за права корінної пригнобленої більшості проти білих колонізаторів. У своїх публіцистичних текстах Стів Біко намагався пробудити поневолені народи ПАР, звільнити їх від почуття расової меншовартості, визволити їх передусім психологічно, а вже потім - фізично. Наскільки нам відомо, Стів Біко не вживав поняття «гегемонія» у грамшіанському сенсі слова, однак його оцінка ситуації із пануванням європейців у ПАР додає багато суттєвого для розкриття природи аналізованого явища.

Стіва Біко непокоїло, що серед борців проти режиму апартеїду провідну роль відіграють білі ліберали (тобто представники привілейованої меншості), а не упосліджені, дискриміновані чорні. Свою найважливішу на цю тему статтю «Чорні душі у білій шкірі?», опубліковану 1970 р. у місячнику SASO Newsletter, Стів Біко розпочинає з твердження: «В основному, південноафриканська біла громада $є$ однорідною. Це спільнота людей, які користуються привілейованим становищем, якого вони не заслуговують...». Цією тезою він одразу ж заперечує існування принципової відмінності між білими націоналістами, які відкрито дискримінують корінне чорне населення, та білими лібералами, які захищають чорних та не хочуть миритися із расистськими порядками: «Це люди, які стверджують, що вони відчувають гноблення 
так само гостро, як чорні, і тому повинні бути залучені у боротьбу чорної людини за місце під сонцем» [12, Р. 20].

Інтеграція між білими лібералами та чорними не принесе, на думку Стіва Біко, нічого доброго останнім, адже люди, яких зібралися інтегрувати, походять із різних, сегрегованих одне від одного суспільств, із добре засвоєними комплексами вищості в одних та неповноцінності в інших, які продовжують проявляти себе навіть у безрасовому об’єднанні. «Результатом досягнутої в такий спосіб інтеграції є односторонні взаємини, в рамках яких білі відповідальні за говоріння, а чорні - за слухання». Стів Біко помічає за білими друзями упосліджених чорних те саме бажання домінувати над тими, кого вони захищають: «Дуже мало чорних організацій не були під білим керівництвом. Вірні своєму образу, білі ліберали завжди знали, що добре для чорношкірих, і казали їм це»; «...Чорні відстоюють себе у суспільстві, у якому їх розглядають як постійних шістнадцятирічних»; «Ніде зарозумілість ліберальної ідеології не продемонстрована настільки добре, як у їхньому наполяганні, що проблеми країни можуть бути вирішені тільки через двосторонній підхід, який включає як чорних, так і білих» [12, Р. 20-21].

Як ідеалістична теорія інтеграція на рівних умовах не викликає заперечень у Стіва Біко, проте автор не бачить для неї алгоритму, адже рівні умови залишатимуться ілюзією, поки чорні страждають на комплекс неповноцінності, а біла людина матиме свої привілеї. Натомість Стів Біко різко відкидає перспективу входу чорних у біле суспільство, асиміляцію чорних у вже встановлений набір норм та кодекс поведінки, який створили та підтримують білі: «Я проти стратифікації «вищий-нижчий», «білий-чорний», що робить білого вічним учителем, а чорного - вічним учнем (і бідним при цьому). Я проти інтелектуальної зарозумілості білих людей, яка схиляє їх до думки, що біле лідерство є sine qua non у цій країні і що білі - це призначені небесами провідники до прогресу. Я проти того, що меншина поселенців повинна нав’язувати цілу систему цінностей корінному народу» [12, Р. 23-24].

Біко повертається до цієї теми у доповіді під назвою «Повнота влади білих у Південній Африці», яку він виголосив на студентській конференції у Кейптауні у січні 1971 р. Тут публіцист знову заявляє, що «найбільшою помилкою для чорного світу було припустити, що усі, хто протистоїть апартеїду, є союзниками». Передусім він має на увазі лібералів, які беруться визначати для чорних людей, за що останні повинні боротися [13, Р. 63]. Заключний пасаж доповіді проілюстрував взаємини чорних та прихильно до них налаштованих білих лібералів у такий спосіб: «Білі не лише були винні в агресії, але й завдяки деяким умілим маніпуляціям зуміли взяти під контроль реакцію чорних на цю провокацію. Вони не лише били чорного, але й казали йому, як реагувати на удар. Довго і терпляче чорний слухав поради про те, як найкраще відповісти на удар. Із болючою повільністю він тепер починає показувати ознаки того, що це його право і обов'язок відповідати на удар так, як він вважає за потрібне» [13, Р. 66].

На противагу цінностям, які білі європейці привезли з собою в Африку, Стів Біко у статті «Ми чорні» закликає повертатися до африканської культури, дискредитованої та несправедливо названої «варварською». Але зробити це буде неможливо, доки африканська дитина «вчиться ненавидіти свій спадок у сучасній школі», доки африканці святкують свята білих на зразок дня Поля Крюгера (бурський державний діяч), дня героїв, дня республіки, забуваючи свої свята та своїх героїв, та доки білі 
стандарти $€$ «критерієм, за яким навіть чорні судять один одного». За зауваженням Біко, «народ без позитивної історії - це автомобіль без двигуна» [14, Р. 29-30].

Важливим чинником психологічної зверхності білих колонізаторів над корінними жителями Південної Африки Стів Біко вважає християнство, «релігію білої людини». Християнські місіонери збили з пантелику африканців із їхньюю новою релігією, - «за якоюсь дивною логікою вони стверджували, що їхня релігія - наукова, а наша - простий забобон» $[15$, Р. 45]. У церкві європейського походження «людей постійно заохочують шукати провину в собі і таким чином відволікають їх від суті боротьби, яку вони ведуть. Позбавлені духовного змісту, чорні читають Біблію із довірливістю, яка шокує. Поки вони хором співають «теa culpa», до них приєднуються групи білих, які співають іншу версію - «tua culpa»» [14, Р. 31]. Контролюючи церкви $[16$, P. 57], білі заохочують покірність та почуття вини серед чорних, вчать їх мовчки терпіти і страждати, в той час як релігія мала б бути ключовим мотором боротьби за свободу. «Жодна нація не може виграти битву без віри, - підкреслює Стів Біко, - i якщо наша віра в нашого Бога зіпсована тим, що ми повинні бачити Його очима того самого народу, проти якого ми воюємо, то, очевидно, щось не так у цих взаєминах» [16, Р. 60]; «Завжди існує взаємозалежність між історією народу, тобто минулим, вірою в себе і надіями на майбутнє. Ми потерпаємо від страшної ролі нашої освіти і релігії у творенні серед нас хибного розуміння себе» [17, Р. 52].

На початок 1970-х років Стів Біко був змушений визнавати, що в результаті політичного, економічного, культурного домінування європейців на глобальному рівні, «білі системи породили по всьому світу чимало людей, які не усвідомлюють, що вони теж люди» [17, Р. 51]. Усе це - наслідки блискуче проаналізованої у текстах Стіва Біко гегемонії колонізаторів, вправного контролю над свідомістю колонізованих через релігію, освіту, медіа тощо, контроль меж дискусії за рахунок контролю як домінантного наративу (ідеологія режиму апартеїду), так і контрнаративу (ідеологія ліберальної, лівої опозиції).

\section{Простір для сучасних інтерпретацій}

Можливостей для більш чи менш близьких аналогій із південноафриканським досвідом гегемонії можна ідентифікувати доволі багато. Це і гегемонія 4-5 олігархів над інформаційним простором України (національний масштаб), і гегемонія сильного медійного ринку над слабким, наприклад, британського над ірландським [див.: 9, С. 213-215] (міжнаціональний масштаб), і гегемонія соціальних мереж над глобальним інформаційним полем, яка з часом лише зростатиме (глобальний масштаб).

Показовим прикладом гегемонії є російська медіасфера. Авторитетний журналіст Владімір Познер зауважує, що якщо держава захоче закрити незалежні медіа, воно їх закриє [18] та що Эхо Москвы та деякі інші опозиційні медіа можуть робити те, чого не можна іншим, оскільки їм це «дозволено» з огляду на малу аудиторію [19]. Таким чином, офіційний Кремль транслює себе через мейнстрімові медіа, водночас контролюючи опозиційні за рахунок можливості будь-якої миті припинити їхне існування. Однак не перекриває їм дихання, оскільки опозиційні медіа виконують низку корисних функцій. Обмежимося чотирма ключовими:

1) Створюють видимість свободи слова та плюралізму думок у країні;

2) 3 профілактичною метою дають можливість незадоволеним громадянам випускати пару; 
3) Маркують опозиційний актив, який, не маючи свого майданчику, залишався б у підпіллі, мімікрував, проникав у провладні медіа тощо.

4) Дискредитують опозицію як «ворогів народу», схильних транслювати антидержавні меседжі.

Висновки. Концепція гегемонії авторства Антоніо Грамші набула особливої актуальності у XXI ст., коли насильницькі методи досягнення мети остаточно поступилися місцем м'якій силі, а контроль над думками, інтерпретаціями, смаками, пріоритетами людей став найважливішим ресурсом. Гегемонія як медійний феномен тісно пов'язана з медійним імперіалізмом, пропагандою 2.0, теорією «agenda setting», спіраллю мовчання, які проявляють себе як її інструментарій.

Стів Біко не користувався грамшіанським поняттям «гегемонія», однак у своїй публіцистиці доволі точно проаналізував та описав це явище на прикладі режиму апартеїду у ПАР, для якого було характерне політичне, економічне, а передусім культурне панування колонізаторів над корінними жителями країни. Приклад апартеїду у ПАР унаочнює, яким чином нечисленна меншість, утримуючи контроль над релігією, освітою, громадським життям, домінує над величезною більшістю населення, яку складали корінні жителі країни. Стів Біко показав, що для забезпечення гегемонії важливо контролювати як панівний наратив, так і контрнаратив, визначаючи таким чином межі дискусії, зберігаючи «владу» і значною мірою впливаючи на «опозицію».

На сучасному етапі поняття «медійна гегемонія» доречне для характеристики інформаційного простору на національному, міжнаціональному та глобальному рівнях. Одним із численних прикладів може бути контроль Кремля над усією палітрою російських медіа - від провладних до відверто опозиційних.

\section{REFERENCES}

1. Тиса Р. Основні поняття політичної теорії Антоніо Грамші [Електронний ресурс] / Роман Тиса. 2011. 29 груд. [цит. 2019, 8 лют.]. Доступно 3 : goo.gl/wEJGng

2. Грамші А. Політичне керівництво кляси до і після взяття влади [Електронний ресурс] / Антоніо Ірамші ; [пер. $з$ італ. «Вперед»]. 2014. 20 берез. [цит. 2019, 8 лют.]. Режим доступу : goo.gl/USDckm

3. Benoist A. de. Gramsci et la conquête du pouvoir culturel / Alain de Benoist // Le Figaro magazine. 1978. 11-12 mars.

4. Рахно К. Комуністичні манівці Алена де Бенуа [Електронний ресурс] / Костянтин Рахно. [цит. 2014, 8 верес.]. Режим доступу : goo.gl/iVmwxF

5. Schinello S. Tutta la nostra intelligenza. Il concetto di egemonia in Gramsci / Salvatore. Schinello. GOG, 2017. 124 p.

6. Altheide, D. L. Media Hegemony. A Failure of Perspective / David. L. Altheide // The Public Opinion Quarterly. 1984. Summer. P. 476-490.

7. Andrews S. J. Hegemony, Mass Media, and Cultural Studies: Properties of Meaning, Power, and Value in Cultural Production / Sean Johnson Andrews. Rowman \& Littlefield International, 2017. $239 \mathrm{p}$.

8. Kranenburg R. van. Whose Gramsci? Right-wing Gramscism [Electronic resource] / Rob van Kranenburg // International Gramsci Society Newsletter. 1999. N 9 (Mar.). [Cit. 2014, 8 Sept.]. Available from: goo.gl/9H4NKm 
9. Бойд-Барретт О. Медиа империализм / Оливер Бойд-Барретт. Харьков : Гуманитарный центр, 2018. 292 с.

10. Почепцов Г. Пропаганда 2.0: Новые измерения в действии // Георгий Почепцов // Media Sapiens. 2015. 5 лип. [цит. 2019, 8 лют.]. Режим доступу : goo.gl/tW448p

11. Почепцов Г. Пропаганда 2.0 / Георгий Почепцов. Харьков : Фолио, 2018. 796 с.

12. Biko S. Black Souls in White Skins? / Steve Biko // I Write What I Like. Heinemann, 1987. P. 19-26.

13. Biko S. White Racism and Black Consciousness / Steve Biko // I Write What I Like. Heinemann, 1987. P. 61-72.

14. Biko S. We Blacks / Steve Biko // I Write What I Like. Heinemann, 1987. P. 27-32

15. Biko S. Some African Cultural Concepts / Steve Biko // I Write What I Like. Heinemann, 1987. P. 40-47.

16. Biko S. The Church as seen by a Young Layman / Steve Biko // I Write What I Like. Heinemann, 1987. P. 54-60.

17. Biko S. The Definition of Black Consciousness / Steve Biko // I Write What I Like. Heinemann, 1987. P. 49-54.

18. Владимир Познер: В России сегодня нет журналистики // Deutsche Welle. - 2015. 25 мая. [цит. 2019, 8 лют.]. Режим доступу : goo.gl/jceCBf

19. Познер и Тина Канделаки о Навальном. Вырезанный кусок // YouTube. 2012. 7 февр. [цит. 2019, 8 лют.]. Режим доступа : goo.gl/43D1hQ 


\title{
MEDIA HEGEMONY OF COLONIZERS IN SOUTH AFRICA: STEVE BIKO'S VISION
}

\author{
Iurii Melnyk \\ Ivan Franko National University of Lviv, \\ Generala Chuprynky Str., 49, 79044, Lviv, Ukraine \\ e-mail: melnykiurii@gmail.com \\ https://orcid.org/0000-0002-2825-9925
}

The article attempts to assess the contribution of South African author Steve Biko to the development of Antonio Gramsci's concept of hegemony. This concept became particularly relevant in the 21st century, when violent methods of goal achieving once and for all gave way to soft power, and control over thoughts, interpretations, tastes, and priorities of people became the most important resource. Hegemony as a media phenomenon is closely linked to media imperialism, propaganda 2.0, the theory of «agenda setting», the spiral of silence that manifest themselves as hegemony's toolkit.

Steve Biko did not use the Gramscian concept of hegemony, but in his journalism he analyzed and described this phenomenon quite accurately on the example of the apartheid regime in South Africa, which was characterized by political, economic, and first of all by cultural domination of the colonialists over the South African people. The example of apartheid in South Africa illustrates how a small minority, holding control over religion, education, and social life, dominated the vast majority of the population, which were the indigenous inhabitants of the country. Steve Biko has shown that it is important to control both the ruling narrative and the counter-narrative in order to ensure hegemony, thus defining the limits of the discussion, preserving «power» and, to a large extent, influencing the «opposition».

At the present stage, the concept of «media hegemony» is appropriate for the characterization of the information space at the national, international and global levels. One of the many examples is the control of the Kremlin over the entire range of Russian media, from pro-government to outright oppositional ones.

Key words: hegemony, Steve Biko, media imperialism, propaganda 2.0, South Africa, apartheid. 